\title{
Man's best friend - mammoth's worst enemy? A speculative essay on the role of dogs in Paleoindian colonization and megafaunal extinction
}

\author{
Stuart J. Fiedel
}

\begin{abstract}
Recent genetic studies indicate that the wolf ancestors of New World dogs were domesticated in East Asia, about 15,000 cal. BP. Although archaeological evidence of the earliest American dogs is very scarce, they probably accompanied the Paleoindians who crossed Beringia and occupied North America after 13,500 cal. BP. By providing humans with hunting assistance and transport capability, as well as an emergency food source, dogs may have facilitated the very rapid expansion of Paleoindians. As hunters or as disease carriers, dogs may also have played a role in megafaunal extinction.
\end{abstract}

\section{Keywords}

Dogs; domestication; genetics; Paleoindians; megafauna.

Introduction: the implications of canine genetics

Two recently published studies of canine mtDNA have greatly clarified the origins of the domestic dog. Comparisons of mtDNA from a global sample of extant dog breeds suggest that the ancestral wolf was domesticated in a single location, probably in eastern Asia, about 15,000 years ago (cal. BP) (Savolainen et al. 2002). Ancient mtDNA sampled from bones of New World dogs indicates that they also are derived from this common ancestral population in Asia, and thus were not independently domesticated from the American grey wolf (as formerly was often assumed) (Leonard et al. 2002). These genetic inferences are consistent with evidence from skeletal morphology. Detailed similarities between the mandibles of pre-Columbian Puebloan dogs and their presumptive ancestors, Chinese wolves, were recognized by Olsen and Olsen (1977). 
Archaeological evidence demonstrates the presence of domesticated dogs by at least 8500 rcbp in North America, and perhaps even earlier in South America. It is a logical and parsimonious inference that dogs were brought along by proto-Paleoindians as they migrated across Beringia c. 13,500-14,000 cal. BP, and they later accompanied the Paleoindians who occupied North America after 13,500 cal. BP.

In this article, I review the sparse archaeological record of the earliest domesticated dogs in East Asia and the Americas. Next, I summarize the varied uses of dogs by historic-era Native American hunting peoples and by Antarctic explorers. On the basis of these ethnographic and historical analogues, I then propose several plausible roles for dogs in Paleoindian hunting, mobility, and subsistence strategies. I suggest that dogs may have facilitated the very rapid expansion of Paleoindians and may also have been a significant causal factor in megafaunal extinction.

\section{The archaeological record of early domesticated dogs}

Until recently, the earliest unambiguous archaeological evidence of domesticated dogs has come from the Near East (Turnbull and Reed 1974; Tchernov and Valla 1997; Davis and Valla 1978) and Europe (Nobis 1981; Hedges et al. 1998), with dates in both areas of $c$. $12,000 \mathrm{rcbp}(14,000 \mathrm{cal}$. BP). However, in view of the new genetic evidence, these occurrences become peripheral to the presumptive 'hearth' of canine domestication, and it is necessary to examine more closely the record of domestication from eastern Eurasia. Two massive wolf-like dogs have been reported recently from Eliseevichi 1 in the Dnieper basin in Russia, dated c. 13,000 to 17,000 rcbp (Sablin and Khlopachev 2002). A skull found in a probable giant hyenas' den within Razboinichiya Cave in the Altai Mountains has been ascribed to an early domestic dog, based upon morphology. Its reported radiocarbon age is about 14,000 rcbp (Turner 2002). It is not clear if the dated sample came from the skull itself, and the procedures used (AMS, amino acid?) are not specified. Might it be intrusive? If this dog was indeed snatched from a human campsite by hyenas, there ought to be traces of Upper Paleolithic habitation in the vicinity of the cave. Until more data are forthcoming about the intra-site and regional contexts of this find, some skepticism may be advisable. At Ushki 1 in Kamchatka, an early dog occurs in a less ambiguous, human association intentionally buried inside a house in Layer VI, dated to c. 10,800 rcbp (Dikov 1996).

Radiocarbon ages of about 14,000 rcbp calibrate to calendar ages of about 16,000 cal. BP, so if the specimens from Eliseevichi 1 and Razboinichiya Cave are correctly identified and dated, they would be slightly earlier than the date of first domestication as calculated by the geneticists. This is not a major discrepancy, in view of the error factors inherent in the genetic estimates for the three broad dog clades: 11,000 + $-4000,16,000+-3000$, and $26,000+-8000$ BP for Clade A, 13,000+-3000 BP for Clade B, and 17,000+-3000 BP for Clade C (Savolainen et al. 2002).

The archaeological record of early dogs in the Americas is meager. One still finds occasional references to bones from Jaguar Cave, Idaho, as representing the earliest North American dog. This dog was once thought to date from about 10,400 rcbp; however, a direct radiocarbon date showed that it was really much younger $-3220+-80$ rcbp (Gowlett et al. 1987: 145-6). A broken dog mandible found in Stratum 4 of Hogup Cave 
probably dates to about $7800+-300 \mathrm{rcbp}$ (Haag 1970). A possible early dog (c. $9000-$ 10,000 rcbp) was identified in Danger Cave, Utah (Grayson 1988). Well-preserved dogs from Nevada have recently been dated directly to $6360+-60$ rcbp (Crypt Cave) and $6290+-40$ rcbp (Earth Mother Cave) (Dansie 1999). The oldest securely identified domesticated dogs in the continent are the three that were intentionally buried about 8500 rcbp within Horizon 11 of the Koster site, in southern Illinois (Struever and Holton 1979: 210; Morey and Wiant 1992).

At the Jones-Miller site in easternmost Colorado, bones of a dog or wolf were recovered from the immediate vicinity of a possible ritual deposit associated with a bison kill. This site is dated by the presence of Hell Gap points to $c$. 10,000 $\mathrm{rcbp}(c .11,500$ cal. BP) (Stanford 1979).

There is some exiguous evidence for still earlier, Paleoindian dogs. At Blackwater Draw in New Mexico, a Clovis kill site dating from about 13,000 cal. BP, 'kennel damage' has been recognized on several tail bones of mammoth. This damage resembled the bone wear that is produced by modern 'sedentary canids... and is typically inflicted by captive or provisioned individuals'; the small size of these bones was suggestive of brief 'gnawing, sucking, licking, and pawing' by a juvenile (Saunders and Daeschler 1994: 21-3). These analysts speculated that 'tamed wild canids [were] present during the processing of these mammoth carcasses'. They noted that at Lehner Ranch and Murray Springs, both Clovis sites in south-eastern Arizona, large and small wolf-like canids had been identified, and Saunders was reported to be undertaking additional study of the two smaller specimens. Evidently, the results were not definitive of domesticated status.

In Fell's Cave, near the southern tip of South America, eighteen teeth and jaw fragments ascribed to Canis familiaris were derived from the lowest strata (dating from $c .11,000$ to $6500 \mathrm{rcbp}$ ). Three of these dog remains were found in the Paleoindian zone (Period I), dated to $c$. 11,000-10,000 rcbp (Clutton-Brock 1988). One of the dog mandibles had been chopped to remove edible matter. The faunal analyst Clutton-Brock was confident that the dog teeth could be distinguished from those of local wild canids; however, in view of the re-dating of the Jaguar Cave dogs, she cautioned that only direct dating of the Fell's Cave bones could preclude the possibility that they were intrusive into the Paleoindian deposits. Dog remains were tentatively identified at Tagua Tagua, a Paleoindian kill site in Chile dating between $c$. 11,000 and $9900 \mathrm{rcbp}$, where Fell 1 fishtail points are associated with bones of gomphothere and horse (Palma 1969). However, the small Tagua Tagua canid might instead be a South American fox (culpeo, Pseudalopex culpaeus). Canids, perhaps dogs, also have been found at Inca Cueva 4 in Argentina (c. 9200 rcbp) and Chobshi Cave, Ecuador (c. $9000 \mathrm{rcbp}$ ) (Lynch 1983: 121), and domesticated dog was reported from Los Toldos Cave 3 in Argentina (c. 7000 rcbp) (Cardich 1977; Miotti and Salemme 1999). Lynch (1983) remarked that dogs could have assisted Paleoindians in 'flushing' grounddwelling birds such as the partridge-like tinamou.

The Siberian forebears of the Paleoindians may already have been using dogs to flush partridges. At Berelekh, in north-east Siberia (western Beringia), an ostensible midden deposit dated between $c .10,600$ and 13,400 rcbp contained, besides mammoth and horse or bison bones, ninety-two bones of partridge (Mochanov and Fedoseeva 1996). Berelekh is one of the very few sites of an appropriate age and at the right location to possibly represent the cultural background from which Clovis ancestors emerged. 
On present evidence, an introduction of dogs to America from the Old World at some time after the migration of the Paleoindians cannot be precluded. However, such a late dispersal cannot be plausibly ascribed to any identifiable subsequent migration from Asia. The eastward movement of the Arctic Small Tool Tradition is much too late (about 4000 rcbp) to account for dogs in the mid-continent before $8500 \mathrm{rcbp}$ (9500 cal. BP). The earlier Paleoarctic microblade makers of Alaska clearly had ancestral ties to Northeast Asia, and contacts between those areas may have persisted for millennia. However, the penetration of microblade industries into the north-western US, around $6000 \mathrm{rcbp}$ (7000 cal. BP), is also too late to account for the arrival of dogs. Of course, dogs might have been exchanged in the absence of any other trait diffusion or human migration. The much later introduction of the bow and arrow from Asia could be an analogous case of long-distance transmission. However, the existence of a unique clade (labeled ' $a$ ') in ancient South American dogs, absent from all modern Eurasian breeds sampled, is interpreted as indicating a 'history of isolation' (Leonard et al. 2002: 1615) of New World dogs; this separate development argues against the occurrence of frequent incursions of Asian dogs in the millennia following initial human migration to North America. In view of the demonstrated presence of dogs in farthest Northeast Asia (Ushki 1) only a few centuries after the presumed date of Paleoindian ancestors' departure, the simplest explanation of the introduction of dogs to North America is that they accompanied Paleoindians as the latter migrated south of the ice sheets around 11,200 rcbp (13,200 cal. BP).

\section{Comparative ethnographic data on the many uses of dogs}

Washburn and Lancaster (1968: 294) lamented the scant attention paid to dogs in presentations at the 'Man the Hunter' conference: 'Although hardly mentioned at the symposium, dogs were of great importance in hunting, for locating, tracking, bringing to bay, and even killing.' They recounted their own observation of an incident in an East African park, where two small dogs brought a rhinoceros to bay; they also remarked that the most successful hunters among the South African San were men assisted by dogs. At the same conference, W. S. Laughlin indelicately noted another important function of dogs: 'Women and dogs have been the principal beasts of burden since Paleolithic times' (1968: 311).

Lowie (1954: 39-42) offered a concise summary of the varied tasks performed by dogs among the Plains Indians. There is a good possibility of direct continuity from Paleoindian practices down to these historic-era cultures, although the late adoption of a bison-hunting lifeway by former agricultural peoples of this region, after the horse became available, must be acknowledged. Plains rituals commonly entailed dog sacrifices, a practice that brings to mind the Jones-Miller site. A few Plains tribes with roots in the Plateau area (e.g. Kutenai and Shoshone) used dogs to help in hunting of deer and elk. Dogs were useful as sentries. Some tribes ate dogs; the Arapaho were particularly known for this practice. Dogs were most important for transport. The Mandan used dog-drawn sleds in the 1830s, but it is suspected that these were a late introduction. Some tribes in the southern Plains placed simple pack saddles on their dogs. A common artifact used by most Plains tribes was a transportation device called the travois. It consisted of two long poles attached at 
the dog's shoulders, with the butt ends dragging behind the animal; midway, a ladder-like frame, or a hoop made of plaited thongs, was stretched between the poles and served to carry loads that might exceed 60 pounds. Henderson (1994) has determined by experimentation that a dog laden with a load of about $13 \mathrm{~kg}$ (under 30 pounds) could achieve a maximum distance of $27 \mathrm{~km}$ (17 miles), in cool weather. A dog-pulled travois might be employed by women to haul firewood. It could be used for meat transport, a quarter of a bison being a suitable load. Tribes living on the Missouri lashed their bullboats - coracle-like craft made of stretched bison hides - onto travois. Many Plains tribes told the tale of a little boy who was strapped to a travois. In view of the diverse utility of dogs, it should not be surprising that the average Arikara family reportedly kept thirty to forty animals.

\section{Paleoindian dogs provide new answers for some old questions}

On the assumption that Paleoindians had dogs at their disposal as they headed south from Beringia, I can suggest new answers to several old questions about the colonization process: 1) How could the migrants sustain themselves in the inhospitable ice-free corridor, if there were no megamammals yet living there? 2) How did people move so far, so fast, from Alaska to Tierra del Fuego in just a few hundred years? 3) How did this mobile population manage to rear children in sufficient numbers to rapidly fill the continent with humans? 4) Given the synchronicity of human expansion and megafaunal extinction, what was their causal connection?

\section{Survival in the 'ice-free corridor'}

Despite much renewed attention to the possibility of a migration route along the Pacific coast (Fladmark 1979; Gruhn 1994; Fedje and Josenhans 2000; Dixon 1999, 2001), there is as yet no compelling evidence that any ancestral Paleoindians took this route. Apart from the absence of any sites earlier than 11,000 rcbp, the barrier posed by a continuous coastal ice mass stretching for hundreds of miles across south-east Alaska obviates the feasibility of a coastal journey in small, simple watercraft (Turner 2003). Instead, the long-accepted migration by an interior route between the receding Laurentide and Cordilleran ice sheets, some time after $c .11,600 \mathrm{rcbp}(c .13,400 \mathrm{cal}$. BP), remains the more plausible alternative (Haynes n.d.) However, the newly deglaciated 'corridor' may have offered few resources for human consumption. It would have taken some time for fish to occupy initially unproductive proglacial lakes, and these water barriers would have impeded migration, whether southward or northward, by terrestrial mammals. There is no evidence of any large mammals migrating south through the corridor before about 10,000 rcbp (11,500 cal. BP), almost two millennia after the Paleoindians trekked through it (Wilson 1996). The earliest inhabitants of central Alaska, about 11,700 rcbp (13,600 cal. BP), derived much of their meat from tundra swans and other migratory waterfowl. Great flocks of these birds, following the corridor route in their annual migration and probably making stopovers on the proglacial lakes, would have provided a familiar food source for the migrating Paleoindians (Fiedel n.d.). Dogs probably were useful in finding, driving, and retrieving 
waterfowl. Watercraft, whether bull-boats or canoes, would have been needed for birdhunting; indeed, they were essential merely to cross large bodies of water such as glacial Lake Peace. Dogs could have hauled these craft on travois, as they did in historic times along the Missouri.

If the supply of birds (and, one assumes, dried pemmican) proved insufficient for the emigrants, there was always an emergency source of dog meat. Roald Amundsen and his Norwegian team famously succeeded in reaching the South Pole in 1911, while Robert Scott's English expedition failed, in large part because of the Norwegians' study and imitation of Inuit survival strategies. Most critical was their unsentimental use of dogs, first to haul sleds and then, as they were less necessary for decreasing loads, as a back-up supply of meat, both for the men and the surviving dogs (Amundsen 1913: ch. 11). Amundsen's round trip overland voyage to the pole covered about 1400 miles; the ice-free corridor was about 1200 miles long.

Amundsen's dogs hauled sledges, on which the men often rode; they were able to traverse about 20 miles a day. The Eskimo sled that was the prototype for the Norwegians' equipment seems to have been a very late invention. However, a wooden runner, part of a surprisingly sophisticated sledge design, was recently found at a remarkably preserved Mesolithic campsite on Zhokhov Island, off the north coast of Siberia (Pitul'ko and Kasparov 1996). This site has multiple radiocarbon dates of about 8000 rcbp. Several bones of domestic dogs were found; although no remains of a harness were recovered, the excavators suggest that the sledge was pulled by dog power. The sophistication of the Zhokhov sledge may imply centuries of prior development, so it is not inconceivable that proto-Paleoindians in Beringia might have used simpler sledges. The bone rods found with a cache of gigantic fluted points at the East Wenatchee site have been interpreted as sledge runners, based upon their superficial resemblance to Eskimo artifacts (Gramly 1993). However, few specialists have given serious consideration to this idea; the rods are generally assumed to have formed part of a weapon assembly.

The Paleoindians must have kept substantial packs of dogs, like historic Plains Indians. The mtDNA analysts (Leonard et al. 2002) recognized five distinct lineages among New World dogs, from which one must postulate the presence of at least five unrelated females in the ancestral pack. This situation is oddly reminiscent of the human mtDNA evidence from the Americas, where there are also five major haplogroups (A, B, C, D, and X). If we envision the original Paleoindian group as a macroband of about 150 people, and assume thirty dogs per family (with the Arikara as a model), they might have begun the 1200-mile trek through the corridor with some 900 dogs in tow. If the trip took 120 days (17 weeks) at about 10 miles per day, and each family of five butchered one dog per week, there would have been almost 400 dogs still alive by the time they saw their first mammoth at the southern end of the corridor.

\section{Rapid movement}

The same advantages provided by dogs for rapid transit through the corridor - mainly, hauling gear and supplies, watercraft, collapsible dwellings, and even infants - would also have facilitated rapid movement across North America. Obviously, with a huge cornucopia of giant herbivores available for the hunting, dogs would no longer have 
been needed as food. The movements of proboscideans between waterholes probably created a network of veritable highways that Clovis hunters could easily follow (Haynes 2002: 210). Dogs would still have been useful for tracking of smaller game. We know that Paleoindians traversed the continent rapidly, because Clovis points are ubiquitous by about 12,950 cal. BP, probably less than 300 years after arrival of the first macroband. By about the same time, Paleoindians making Fell 1 fishtail points had reached Tierra del Fuego (Fiedel 2000, 2002).

\section{Filling the continent with people}

An objection often raised against the idea that Clovis people rapidly filled the continent is that such a demographic explosion would be impossible, by analogy with recent huntergatherers. Foraging people have to be mobile, and a woman can carry and suckle only one child at a time. This fact alone dictates a three- to four-year spacing between births. Assuming also a late age of menarche and high infant mortality, these numbers leave little time to generate the four to eight surviving children that must be postulated, per woman, in order to achieve a population of several hundred thousand within the 300 or 400 years available, on archaeological evidence, for Clovis expansion. However, Surovell (2000) has demonstrated by mathematical modeling that high mobility, characterized by frequent camp-shifting, theoretically reduces the distances over which women must carry food and infants. Put succinctly, 'if carrying costs are low fertility can be high' (Surovell 2000: 495). The Ache of Paraguay provide a good ethnographic example of this principle: they traditionally shifted camps at least every two weeks, and the women averaged 8.09 births each (Hill and Hurtado 1996). If Paleoindian women could each bear eight children, and most of those, in the absence of human-specific diseases in a virgin continent, survived to adulthood, the Clovis population could have risen from 150 to over 150,000 in 150 years. Using the slightly lower rate of intrinsic population growth advocated by Birdsell (1968) tripling per generation, with a generation defined as thirty years - it would take only 180 years to reach over 100,000. Reasonable estimates of Clovis population in North America, by analogy with recent Sub-Arctic hunters, are on the order of 25,000 to 50,000 (Fiedel 2000; Haynes 2002). By relieving women of the burden of toting firewood, food stores, huts, and infants, dogs would have markedly reduced carrying costs, made residential relocations much easier, and thus allowed Paleoindian women to maximize their fertility.

\section{Human expansion and megafaunal extinction: hunting or disease?}

Domesticated dogs could have contributed to the extinction of American megafauna in three ways, which are not necessarily mutually exclusive: (1) Dogs assisted in the tracking and immobilizing ('bringing to bay') of giant herbivores, which could be more easily dispatched by people. The need for surplus meat to feed large dependent dog packs could have been a motivation for additional kills beyond the basic nutritional requirements of the human hunters. (2) Dogs, serving as camp sentries, warned people of the approach of dangerous nocturnal carnivores. They harried native carnivores with which humans were in direct competition. Exacerbated inter-carnivore rivalry, in a context of rapid climatic changes, may have caused ecosystem perturbation and ultimate collapse. (3) Dogs 
transmitted one or more Eurasian diseases to New World carnivores, provoking a devastating trans-specific epidemic (MacPhee and Marx 1997).

A. Turner (1992) has suggested that large carnivores kept early hominins out of most of Europe until about 500,000 BP, when the decline of giant hyenas and giant cats opened up a new scavenging niche for Homo. In view of the weapon-wielding capabilities of European Homo by c. 400,000 BP, as recently demonstrated by the remarkable Schoningen spears (Thieme 1997), it may be appropriate to reconsider the case as one of direct competition, with the hominins' spread seen as cause rather than consequence. By the time that anatomically modern humans started to expand into Northeastern Asia, probably before 40,000 rcbp, they were certainly proficient hunters, doubtless capable of dispatching even the top carnivores in any region (including, it would seem, the Neanderthals as well as cave bears in Europe [Grayson and Delpech 2003] and late Homo erectus in southern Asia).

However, C. Turner (2002) has suggested that humans may have been deterred from entering western Beringia by giant hyenas. Only with the assistance of newly domesticated dogs, he speculates, could they have successfully confronted those carnivores. After traversing western Beringia, Paleoindian ancestors would again have faced some formidable predators, such as lions and brown bears, in eastern Beringia, but apparently they would not yet have encountered the giant short-faced bear, Arctodus simus. Geist (1999) proposed that humans were kept out of North America by Arctodus. He observed that the native people of California found it hard enough to cope with brown bears ('grizzlies') and generally tried to avoid them. It would have been even more difficult to handle Arctodus, which was bigger, probably faster, and more exclusively carnivorous than the brown bear. The Alaskan record shows that, while Arctodus prevailed there from 35,000 to $21,000 \mathrm{rcbp}$, brown bears were absent, presumably due to competitive exclusion (Barnes et al. 2002). After 21,000 rcbp, Alaska was occupied solely by the brown bear, as the short-faced bear retreated south. Direct dates on Arctodus bones from Sheriden Cave in Ohio (Tankersley 1997) show that it survived in the mid-continent at least to c. 11,100 rcbp, so it was still around to threaten the first Clovis pioneers as they emerged from the corridor.

Were atlatl-launched Clovis points effective against this enormous and aggressive bear? In 1805, Lewis and Clark's men, armed with Pennsylvania ('Kentucky') long rifles, had a very difficult time downing grizzly bears. Lewis expressed a healthy fear of this 'monstrous beast': 'These bear being so hard to die rather intimidates us all....There is no other chance to conquer them by a single shot but by shooting them through the brains, and this becomes difficult in consequence of two large muscles which cover the sides of the forehead and the sharp projection of the center of the frontal bone, which is also of a pretty good thickness.' He was confident of his safety against bears when armed in the woods, but admitted, 'I... feel myself a little diffident with respect to an attack in the open plains' (Lewis 1969 [1805]: 25, 28).

The literature on hunting, world-wide, is replete with descriptions of the use of trained dogs to hunt bears, e.g. in Finland and Siberia. In North America, both native people and frontiersmen hunted bear with dogs, including the famous Davy Crockett, who used a pack of eight dogs to chase black bears (Crockett 1987 [1834]). Paleoindians may have found the assistance of dogs invaluable in confrontations with Arctodus. Even so, it is a 
curious fact that early Paleoindians seem to have avoided caves and rockshelters in North America, but frequently inhabited caves in Central and South America. Arctodus, which did not range south of Mexico, is known to have denned in caves; is it a coincidence that human use of such sites resumed only when the Paleoindians had journeyed beyond the southern range of this dangerous competitor? In North America, people of the Dalton culture began to use caves after about 12,500 cal. BP (Walthall 1998). Perhaps this had less to do with changes in seasonal activities or landscape perceptions than with the final extermination of the short-faced bear.

Apart from the giant short-faced bear, the North American carnivore guild included lion, saber-tooth, dire wolf, and cheetah, all of which went extinct at the end of the Pleistocene, as well as cougars and other smaller predators that survived into the Holocene. The usual assumption is that the demise of the largest predators was a consequence of the disappearance of their megaherbivore prey, whether the extinction of the latter by c. 10,700 rcbp (12,700 cal. BP) was caused by climate change (Grayson and Meltzer 2003) or human predation (Martin 1984; Fiedel and Haynes 2004). Even if one prefers the latter explanation, as I do, the classic 'blitzkrieg' model of overkill (Mosimann and Martin 1975; Alroy 2001) seems to be premised on unrealistic demographic parameters. Judging from the numbers of Clovis sites and isolated points (about 12,000) that have been found in North America, it appears improbable that Paleoindian population ever reached the 500,000 to 1 million humans that are required in these models to achieve total overkill within about 300 to 400 years after arrival. Also, the ostensible clustering of fluted point finds in certain regions, such as riverine confluences in the midSouth (Anderson and Faught 2000), suggests that the Paleoindian migration followed a 'leap-frog' instead of a 'wave of advance' pattern (Anderson and Gillam 2000). Martin's model requires the wave-front to block megafauna from escaping into the area behind the constantly advancing front. If Clovis population peaked instead at only about 25-50,000 (Haynes 2002; Fiedel 2000), would there have been enough hunters to wipe out several million megafauna (Haynes [2004] postulates a reasonable figure of some 800,000 mammoths alone)?

It seems that a satisfying solution to this problem must entail complex interactions among humans, megaherbivores, and the indigenous top carnivores. Whitney-Smith (2002) has proposed a 'second-order overkill' model. In her rough computer simulation, if humans selectively attack predators, an increase of about 2 per cent in the latter's annual death rate causes their extinction while it throws their habitual prey animals first into a population boom, followed by a crash. Modest human predation after the crash could finish off many herbivore species. The idea of a post-predator-demise boom and bust is concordant with Kay's (2002) argument that it was intense predation, not limited food supply, that had severely constrained the populations of North American Pleistocene herbivores. As in any ecosystem, the total population of American carnivores must have been less than about 10 per cent of the herbivore population. Therefore, setting aside the relative physical risks to the hunter of targeting carnivores instead of herbivores, it does appear theoretically easier to drive the former to extinction. It would be churlish to object that no archaeological evidence has been found of such concentrated killing of carnivores in North America, since the only unambiguously attested Paleoindian kill sites contain only mammoths (Grayson and Meltzer 2002). Nevertheless, the Zhokhov Island site in 
Arctic Siberia, previously mentioned for its sledge and dog remains from 8000 rcbp, offers a startling potential analogue for such hunting behavior. The primary prey here was the polar bear, with secondary hunting of reindeer (Pitul'ko and Kasparov 1996). Perhaps Paleoindians, like these Siberian Mesolithic hunters, indeed selectively targeted carnivores, whether for food or to exterminate dangerous competitors. In any case, the arrival of Paleoindians probably initiated a sort of 'musical chairs' scenario, as the native predators were pushed into more intense competition over decreasing numbers of megaherbivores in a time of abrupt climatic changes.

An important aspect of Martin's overkill model is the presumption of naïvete of American megafauna, which had no idea how dangerous humans could be. However, field studies of moose reacting to the reintroduction of wolves show that they grow wary of the new predators after only one generation of experience (Berger et al. 2001). By inference from this analogous case, it would appear that humans would have had to finish off the megafauna of any given area within about thirty years. This might work with the advancing front model, but does not seem feasible as part of a leapfrog model. The hypothesis of dog-assisted hunting offers a plausible solution. Once their initial naïveté had worn off, when harried by dogs, big herbivores would have assumed the sort of static defensive mode they had always used with some success against dire wolves and other carnivores (as still seen today in the muskox) - a strategy that was useless against the atlatl-thrown spears of human hunters.

The abrupt demise of the American megafauna occurred so soon after the arrival of humans that some have found it inconceivable that hunting alone could have been the cause. MacPhee and Marx (1997) hypothesized that a virulent hyper-disease, inadvertently introduced by humans or by their $\operatorname{dogs}$, might have been the agent of extinction. Few modern diseases are both frequently fatal and also capable of jumping across species; one of these few is canine distemper, which is caused by a morbillivirus. In 1993-4, lions in the Serengeti National Park in Tanzania were infected by this virus, evidently transmitted by domestic dogs living on the park's perimeter. About 1,000 of the 3,000 infected lions died. Within months, the epidemic had spread to the Maasai Mara reserve in Kenya, infecting lions, hyenas, foxes, and leopards (Roelke-Parker et al. 1996). Distemper is reported to affect not only canids, felids, and hyaenids but also ailurids (pandas), mustelids (e.g. ferrets), procyonids (raccoons), ursids (bear), and viverrids (e.g. civets), and has even infected collared peccaries (Tayassu tajacu) in Arizona (Appel and Summers 1995). The antiquity of this disease has not been established, so we do not know if late Pleistocene dogs could have been carriers (most infected dogs are asymptomatic). Unfortunately, to date, all efforts to identify viral pathogens in Pleistocene fauna have been fruitless.

\section{Conclusion}

Clearly, archaeologists attempting to address the issues raised in this frankly speculative discussion will face the possibly insuperable challenge of inadequate hard evidence. At the outset, an obvious objection should be raised and answered: where are the physical remains of the many thousands of dogs that hypothetically roamed the American continent in the centuries after 13,000 cal. BP? As an instructive comparison, we should 
consider the record of earliest human occupation in North America. Had they not left behind their imperishable and highly distinctive stone spearpoints, we would hardly know that the Paleoindians had been here. Well over 100,000 Clovis people must have died during the two or three centuries after the first band arrived, yet the sole skeletal representative of this population found to date is the infant buried at the Anzick site in Montana (Owsley and Hunt 2001). Given that Paleoindians probably disposed of their dead dogs less ceremoniously than deceased humans, it may be quite some time before well-preserved canid remains turn up that will provide concrete verification of inferences drawn from the genetic evidence.

Nevertheless, a complete re-thinking of the cultural context and significance of dog domestication is already required. Domestication was not initiated by sedentary Mesolithic foragers in the Near East and Europe, nor did it happen independently in the nascent Archaic villages of the Midwest and Mesoamerica. Instead, genetic evidence now points to East Asia as the place where the wolf was first domesticated by mobile, late Upper Paleolithic hunting peoples. The dog was soon put to good use by northern hunters. As Christy Turner has stated, 'The key Late Pleistocene inventions that are needed to endure and traverse the extremely hostile...winter environment above the Arctic Circle are tailored windtight fur clothing, and dogs to aid in transporting the bulky equipment needed for high Arctic survival' (2002: 145). Reliance on dogs, particularly for transport, but also for hunting assistance, food, and protection from carnivores, helps to explain those aspects of Paleoindian behavior that often have been viewed as inconceivable and improbable: their rapid traversal of an inhospitable near-Arctic passage between the ice sheets; their high rates of reproduction and territorial expansion that filled North and South America with people in about 400 years; and their destruction of the American megafauna.

Louis Berger Group Inc., $2300 \mathrm{~N}$ Street $N W$

Washington, DC 20037, USA

sfiedel@louisberger.com

\section{References}

Alroy, J. 2001. A multispecies overkill simulation of the end-Pleistocene megafaunal mass extinction. Science, 292: 1893-6.

Amundsen, R. 1913. The South Pole, an Account of the Norwegian Antarctic Expedition in the 'Fram', 1910-1912, trans. A. G. Chater. London: J. Murray.

Anderson, D. G. and Faught, M. K. 2000. Paleoindian artefact distributions: evidence and implications. Antiquity, 74: 507-13.

Anderson, D. G. and Gillam, C. 2000. Paleoindian colonization of the Americas: implications from an examination of physiography, demography, and artifact distribution. American Antiquity, 65(1): 43-66.

Appel, M. J. G. and Summers, B. A. 1995. Pathogenicity of morbilliviruses for terrestrial carnivores. Veterinary Microbiology, 44(2-4): 187-91. 
Barnes, I., Matheus, P., Shapiro, B., Jensen, D. and Cooper, A. 2002. Dynamics of Pleistocene population extinctions in Beringian brown bears. Science, 295: 2267-70.

Berger, J., Swenson, J. E., and Persson, I.-L. 2001. Recolonizing carnivores and naïve prey: conservation lessons from Pleistocene extinctions. Science, 291(5506): 1036-9.

Birdsell, J. B. 1968. Some predictions for the Pleistocene based on equilibrium systems among recent hunter-gatherers. In Man the Hunter (eds R. B. Lee and I. DeVore). Chicago, IL: Aldine-Atherton, pp. 229-40.

Cardich, A. 1977. Presencia de Canis familiaris en restos arqueologicos de los Toldos, Argentina. Relaciones de la Sociedad Argentina de Antropología, 11: 115-19.

Clutton-Brock, J. 1988. The carnivore remains excavated at Fell's Cave in 1970. In Travels and Archaeology in South Chile (J. Bird, ed. J. Hyslop). Iowa City: University of Iowa Press, pp. 188-95.

Crockett, D. 1987 [1834]. A Narrative of the Life of David Crockett, of the State of Tennessee (ed. P. A. Hutton). Lincoln, NB: University of Nebraska Press.

Dansie, A. 1999. Man's oldest best friends: ancient dogs in Nevada. Nevada State Museum Newsletter, 27(3).

Davis, S. J. M. and Valla, F. R. 1978. Evidence for the domestication of the dog 12,000 years ago in the Natufian of Israel. Nature, 276: 608-10.

Dikov, N. N. 1996. The Ushki sites, Kamchatka Peninsula. In American Beginnings (ed. F. H. West). Chicago, IL: University of Chicago Press, pp. 244-50

Dixon, E. J. 1999. Bones, Boats, and Bison: Archeology and the First Colonization of Western North America. Albuquerque, NM: University of New Mexico Press.

Dixon, E. J. 2000. Human colonization of the Americas: timing, technology and process. Quaternary Science Reviews, 20: 277-99.

Fedje, D. W. and Josenhans, H. 2000. Drowned forests and archaeology on the continental shelf of British Columbia, Canada. Geology, 28(2): 99-102.

Fiedel, S. J. 2000. The peopling of the New World: present evidence, new theories, and future directions. Journal of Archaeological Research, 8(1): 39-103.

Fiedel, S. J. 2002. Initial human colonization of the Americas: an overview of the issues and the evidence. Radiocarbon, 44(2): 407-36.

Fiedel, S. J. n.d. Quacks in the ice: waterfowl, Paleoindians and the discovery of America. In Foragers of the Terminal Pleistocene (eds R. Walker and B. Driskell). Lincoln, NB: University of Nebraska Press, in press.

Fiedel, S. and Haynes, G. 2004. A premature burial: comments on Grayson and Meltzer's 'requiem for overkill'. Journal of Archaeological Science, 31(1): 121-31.

Fladmark, K. R. 1979. Routes: alternate migration corridors for early man in North America. American Antiquity, 44: 55-69.

Geist, V. 1999. Periglacial ecology, large mammals, and their significance to human biology. In Ice Age Peoples of North America: Environments, Origins, and Adaptations of the First Americans (eds R. Bonnichsen and K. Turnmire). Corvallis, OR: Center for the Study of the First Americans, pp. 78-94.

Gowlett, J. A. J., Hedges, R. E. M., Law, I. A. and Perry, C. 1987. Radiocarbon dates from the Oxford AMS system: archaeometry datelist 5. Archaeometry, 29(1): 125-55.

Gramly, R. M. 1993. The Richey Clovis Cache: Earliest Americans along the Columbia River. New York: Persimmon Press.

Grayson, D. K. 1988. Danger Cave, Last Supper Cave, and Hanging Rock Shelter: the faunas. Anthropological Papers of the American Museum of Natural History, 66(1). 
Grayson, D. K. and Delpech, F. 2003. Ungulates and the Middle-to-Upper Paleolithic transition at Grotte XVI (Dordogne, France). Journal of Archaeological Science, 30(12): 1633-48.

Grayson, D. K. and Meltzer, D. J. 2002. Clovis hunting and large mammal extinction: a critical review of the evidence. Journal of World Prehistory, 16: 313-59.

Grayson, D. K. and Meltzer, D. J. 2003. A requiem for North American overkill. Journal of Archaeological Science, 30: 585-93.

Gruhn, R. 1994. The Pacific Coast route of initial entry: an overview. In Method and Theory for Investigating the Peopling of the Americas (eds R. Bonnichsen and D. G. Steele). Corvallis, OR: Center for the Study of the First Americans, pp. 249-56.

Haag, W. G. 1970. Dog remains from Hogup Cave. Appendix VIII in Hogup Cave (ed. C. M. Aikens). Salt Lake City, UT: University of Utah Anthropological Papers 93, pp. 273-4.

Haynes, C. V. n.d. Clovis progenitors: from Swan Point, Alaska, to Anzick site, Montana, in less than a decade? Proceedings of the 2001 Chacmool Conference. Calgary: University of Calgary Press, in press.

Haynes, G. 2002. The Early Settlement of North America: The Clovis Era. Cambridge: Cambridge University Press.

Haynes, G. 2004. Clovis megafauna-hunting: opportunistic, not always optimal, and a better explanation for extinctions. Paper presented at 69th annual meeting of Society for American Archaeology, Montreal, 3 April.

Hedges, R. E. M., Pettitt, P. B., Ramsey, C. B. and van Klinken, G. J. 1998. Radiocarbon dates from the Oxford AMS system: archaeometry datelist 25. Archaeometry, 40(1): 227-39.

Henderson, N. 1994. Replicating dog travois travel on the northern Plains. Plains Anthropologist, 39(148): 145-59.

Hill, K. and Hurtado, A. M. 1996. Ache Life History: The Ecology and Demography of a Foraging People. New York: de Gruyter.

Kay, C. E. 2002. False gods, ecological myths, and biological reality. In Wilderness and Political Ecology (eds C. E. Kay and R. T. Simmons). Salt Lake City, UT: University of Utah Press, pp. 238-61.

Laughlin, W. S. 1968. Hunting: an integrating biobehavior system and its evolutionary importance. In Man the Hunter (eds R. B. Lee and I. DeVore). Chicago, IL: Aldine-Atherton, pp. 304-20.

Leonard, J. A., Wayne, R. K., Wheeler, J., Valadez, R., Guillen, S. and Vila, C. 2002. Ancient DNA evidence for Old World origin of New World dogs. Science, 298: 1613-16.

Lewis, M. 1969 [1805]. Original Journals of the Lewis and Clark Expedition 1804-1806 (ed. R. G. Thwaite). New York: Arno Press.

Lowie, R. H. 1954. Indians of the Plains. New York: McGraw-Hill.

Lynch, T. 1983. The Paleo-Indians. In Ancient South Americans (ed. J. D. Jennings). San Francisco, CA: Freeman, pp. 86-137.

MacPhee, R. D. E. and Marx, P. A. 1997. The 40,000 year plague: humans, hyperdisease and firstcontact extinctions. In Natural Change and Human Impact in Madagascar (eds S. Goodman and B. Patterson). Washington, DC: Smithsonian Institution Press, pp. 169-217.

Martin, P. S. 1984. Prehistoric overkill: the global model. In Quaternary Extinctions: A Prehistoric Revolution (eds P. S. Martin and R. G. Klein). Tucson, AZ: University of Arizona Press, pp. 354-403.

Miotti, L. and Salemme, M. 1999. Biodiversity, taxonomic richness and specialists-generalists during Late Pleistocene/Early Holocene times in Pampa and Patagonia (Argentina, Southern South America). Quaternary International, 53-4: 53-68. 


\section{Stuart J. Fiedel}

Mochanov, Y. A. and Fedoseeva, S. A. 1996. Berelekh, Allakhovsk region. In American Beginnings (ed. F. H. West). Chicago, IL: University of Chicago Press, pp. 218-22.

Morey, D. F. and Wiant, M. D. 1992. Early Holocene domestic dog burials from the North American Midwest. Current Anthropology, 33(2): 224-9.

Mosimann, J. E. and Martin, P. S. 1975. Simulating overkill by Paleoindians. American Scientist, 63 : 304-13.

Nobis, G. 1981. Aus Bonn: das alteste Haustier des Menschen: Unterkiefer eines hundes aus dem Magdaleniengrab von Bonn-Oberkasell. Bonn: Das Reinische Landesmuseum.

Olsen, S. J. and Olsen, J. W. 1977. The Chinese wolf, ancestor of New World dogs. Science 197(4303): 533-5.

Owsley, D. W. and Hunt, D. R. 2001. Clovis and Early Archaic crania from the Anzick site (24PA506), Park County, Montana. Plains Anthropologist, 46: 115-24.

Palma, J. 1969. El sitio de Tagua-Tagua en el ambito Paleo-Americano. Actos del V Congreso Nacional de Arqueologia, Museo Arqueologico de La Serena, Chile, pp. 315-25.

Pitul'ko, V. V. and Kasparov, A. K. 1996. Ancient Arctic hunters: material culture and survival strategy. Arctic Anthropology, 33(1): 1-36.

Roelke-Parker, M. E., Munson, L., Packer, C., Kock, R., Cleaveland, S., Carpenter, M., O’Brien, S. J., Pospischil, A., Hofmann-Lehmann, R., Lutz, H., Mwamengele, G. L. M., Mgasa, M. N., Machange, G. A., Summers, B. A. and Appel, M. J. G. 1996. A canine distemper virus epidemic in Serengeti lions (Panthera leo). Nature, 379(6564): 441-5.

Sablin, M. V. and Khlopachev, G. A. 2002. The earliest Ice Age dogs: evidence from Eliseevichi 1. Current Anthropology, 43(5): 795-8.

Saunders, J. J. and Daeschler, E. B. 1994. Descriptive analyses and taphonomical observations of culturally-modified mammoths excavated at 'the gravel pit,' near Clovis, New Mexico in 1936. Proceedings of the Academy of Natural Sciences of Philadelphia, 145: 1-28.

Savolainen, P., Zhang, Y., Luo, J., Lundeberg, J. and Leitner, T. 2002. Genetic evidence for an East Asian origin of domestic dogs. Science, 298: 1610-13.

Stanford, D. 1979. Bison kill by Ice Age hunters. National Geographic, 155(1): 114-21.

Struever, S. and Holton, F. A. 1979. Koster: Americans in Search of Their Prehistoric Past. New York: Doubleday.

Surovell, T. A. 2000. Early Paleoindian women, children, mobility, and fertility. American Antiquity, 65(3): 493-508.

Tankersley, K. B. 1997. Sheriden: a Clovis cave site in eastern North America. Geoarchaeology, 12(6): 713-24.

Tchernov, E. and Valla, F. R. 1997. Two new dogs, and other Natufian dogs, from the southern Levant. Journal of Archaeological Science, 24: 65-95.

Thieme, H. 1997. Lower Paleolithic hunting spears from Germany. Nature, 385: 807-10.

Turnbull, P. F. and Reed, C. A. 1974. The fauna from the terminal Pleistocene of Palegawra Cave. Fieldiana, 63(3).

Turner, A. 1992. Large carnivores and earliest European hominids: changing determinants of resource availability during the Lower and Middle Pleistocene. Journal of Human Evolution, 22: 109-26.

Turner, C. G. II. 2002. Teeth, needles, dogs, and Siberia: bioarchaeological evidence for the colonization of the New World. In The First Americans: The Pleistocene Colonization of the New World (ed. N. G. Jablonski). San Francisco, CA: Memoirs of the California Academy of Sciences 27, pp. 123-58. 
Turner, C. G. II. 2003. Three ounces of sea shells and one fish bone do not a coastal migration make. American Antiquity, 68(2): 391-5.

Walthall, J. A. 1998. Rockshelters and hunter-gatherers: adaptation to the Pleistocene/Holocene transition. American Antiquity, 63(2): 223-38.

Washburn, S. L. and Lancaster, C. S. 1968. The evolution of hunting. In Man the Hunter (eds R. B. Lee and I. DeVore). Chicago, IL: Aldine-Atherton, pp. 293-303.

Whitney-Smith, E. 2002. Anthropogenic extinctions - overkill, secondary order predation, environmental degradation: a systems dynamics simulation tool. Paper presented at 67 th annual meeting of Society for American Archaeology, Denver, 20-4 March.

Wilson, M. C. 1996. Late Quaternary vertebrates and the opening of the ice-free corridor, with special reference to the genus Bison. Quaternary International, 32: 97-105.

Stuart J. Fiedel received his BA in Anthropology from Columbia University in 1973, and his $\mathrm{PhD}$ in Anthropology from the University of Pennsylvania in 1979. He is author of Prehistory of the Americas (Cambridge University Press, 1987, revised 1992) as well as numerous articles on diverse topics including Paleoindian origins, radiocarbon dating, Neolithic Europe, migration theory, Pleistocene and Holocene climate change, Algonquian languages, and residue analysis. He currently supervised archaeological research projects and historic preservation studies as Senior Archaeologists for the Louis Berger Group in Washington, DC. 